\title{
Effect of informative seminars during national acne week on participants' knowledge about acne in Turkey
}

\author{
Türkiye'de ulusal akne haftasında yapılan bilgilendirme seminerlerinin katılımaların \\ akne hakkındaki bilgi düzeylerine etkisi
}

\section{Hatice Kaya Özden, ๑ Kamer Gündüz*, ๑ Hamdi Özcan**, ๑ Aysun Șikar Aktürk***, ๑ Filiz Topaloğlu Demir****, ๑ Tuğba Özkök Akbulut*****, ๑ Ayșe Serap Karadağ*****}

University of Health Sciences Turkey, Derince Training and Research Hospital, Clinic of Dermatology, Kocaeli, Turkey *Manisa Celal Bayar University, Department of Dermatology, Manisa, Turkey **Bașkent University, Zübeyde Hanım Application and Research Center, Department of Dermatology, İzmir, Turkey ***Kocaeli University Faculty of Medicine, Department of Dermatology, Kocaeli, Turkey ****Bağcılar Medipol Mega University Hospital, Clinic of Dermatology, İstanbul, Turkey *****istanbul Haseki Training and Research Hospital, Clinic of Dermatology, İstanbul, Turkey ******Memorial Atasehir Hospital, Department of Dermatology, İstanbul, Turkey

\footnotetext{
Abstract

Background and Design: To investigate the contribution of informative presentations about acne vulgaris and questionnaires administered before and after informative meetings on patients' awareness and consciousness.

Materials and Methods: Participants were asked to fill out a 20-question survey before and after informative seminars in hospitals and secondary and high schools as part of National Acne Week. The level of statistical significance was set as $p \leq 0.05$.

Results: A total of 466 participants completed the survey before and after the seminar, and the mean age of the participants was $17.4 \pm 6.9$ Before the seminar, $31.1 \%$ of participants thought that acne is originated from the liver, whereas this figure decreased to $16.7 \%$ after the seminar. In all, $47.6 \%$ of participants consulted doctors and $23.9 \%$ consulted social media to seek information about acne; however, after receiving training, $77 \%$ preferred to consult a doctor. Of the participants, $51.1 \%$ were expecting to see the results of acne treatment in 1 or 2 weeks, whereas $83.3 \%$ stated that the effects would be seen in 2 or 3 months after the seminar. When the participants' educational background was grouped as "secondary-high school-other," a statistically significant difference was obtained $(p<0.05)$.

Conclusion: Our study features both patients' misconceptions and their incorrect attitudes about acne, and their level of knowledge improved significantly as a result of educational seminars. The relative benefit derived from educational seminars was positively related to the participants' highest level of education.

Keywords: Acne vulgaris, patient education, beliefs, attitude

Öz

Amaç: Akne vulgaris ile ilgili bilgilendirme toplantısı öncesi ve sonrasında uygulanan anket formları ile bilgilendirici sunumların akne hakkındaki farkındalık ve bilinç düzeylerine katkııını incelemek amaçlanmaktadır.

Gereç ve Yöntem: Ulusal Akne Haftası kapsamında hastane, ortaokul ve lise dengi okullarda verilen bilinçlendirme eğitimi öncesi ve sonrasında katılımcılardan 20 soruluk bir anket doldurmaları istendi. istatistiksel anlamlıık düzeyi $p \leq 0,05$ olarak kabul edildi.

Address for Correspondence/Yazışma Adresi: Hatice Kaya Özden MD, University of Health Sciences Turkey, Derince Training and Research Hospital, Clinic of Dermatology, Kocaeli, Turkey Phone: +90 5052347287 E-mail: hatcek@gmail.com Received/Geliş Tarihi: 27.02.2020 Accepted/Kabul Tarihi: 15.06.2020 ORCID: orcid.org/0000-0003-0203-272X

(C) Copyright 2021 by Turkish Society of Dermatology and Venereology

Turkderm - Turkish Archives of Dermatology and Venereology published by Galenos Yayınevi.
} 


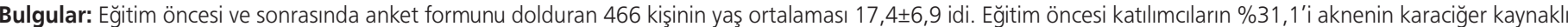
olduğunu düşünürken, eğitim sonrası bu oran \%16,7'ye indi. Akne hakkında bilgi almak için eğitim öncesi katılımcıların \%47,6'sı doktora, \%23,9'u sosyal medyaya başvururken, eğitim sonrası \%77'si doktora başvurmayı tercih edeceğini belirtti. Katılımcıların \%51,1'i akne tedavisinin 1-2 hafta içerisinde etkisini göstereceğini beklerken, eğitim sonrası \%83,3'ü 2-3 ay kullandıktan sonra yanıt alınabileceğini belirtti. Kişilerin öğrenim durumları, "ortaokul-lise-diğer" olarak gruplandırıldığında, eğitim sonrası gruplar arasında öğrenim durumlarına göre istatistiksel olarak anlamlı bir farklılık saptandı $(p=0,005)$.

Sonuç: Çalışmamız bireylerin hem akne hakkındaki yanlış bilgi ve tutumlarını ön plana çıkarmakta, hem de hekimlerin vereceği eğitim seminerleri ve bilgilendirme toplantıları ile bilgi düzeylerinde kayda değer bir gelişme sağlanacağını göstermektedir.

Anahtar Kelimeler: Akne vulgaris, hasta eğitimi, inanç, tutum

\section{Introduction}

Acne vulgaris is a chronic inflammatory disease of the pilosebaceous unit, seen $76 \%$ of adolescent females and $91 \%$ of adolescent males. In adults, the condition occurs more frequently in females. This common situation causes scars and leads to cosmetic, physical, and psychosocial problems ${ }^{1}$. Although there are many studies on the pathogenesis and treatment of acne, research on patients' perception, beliefs, behaviors, and attitudes toward acne is scarce ${ }^{1-9}$. Moreover, no studies on individuals' awareness about acne resulting from an educational platform are available.

\section{Materials and Methods}

\section{Patients and study design}

Informative slideshows were prepared in cooperation with the Acne Study Group and announced to all dermatologists by means of the Turkish Society of Dermatology. These slide projections were presented in hospitals and secondary and high schools during National Acne Week by volunteer dermatologists. İstanbul Medeniyet University, Göztepe Training and Research Hospital Local Ethics Committee approval was obtained (approval number: 2019/0113). After written informed consent was obtained, a questionnaire consisting of 20 questions was administered before and after educational seminars in centers that consented to participate in the study, and it contained questions about their demographic information and their knowledge and attitudes about acne (Table 1). Out of 793 participants that accepted to take part in the educational seminar and the survey, 466 agreed to complete the questionnaire after the seminar.

\section{Statistical Analysis}

The results of the current study were analyzed with IBM SPSS Statistics, Version 21 (Armonk, NY: IBM Corp.) forming a comparative prospective control group. The level of statistical significance was set as $p \leq 0.05$. Chi-square analysis was conducted to compare individuals' educational background and their level of knowledge on acne.

\section{Results}

In total, 466 people (male: 99, female: 367) who participated in the seminars and who completed the questionnaire before and after the seminars were evaluated in the current study. The mean participant age was $17.4 \pm 6.9(10-58)$. Overall, $72.1 \%$ of the participants were high school students, $16.3 \%$ were secondary school students, $3.2 \%$ were university students, and $8.4 \%$ were classified as non-students (graduate, retired, and housewife). Of the participants, 41\% (191) stated that they had not previously suffered from acne problems, and $59 \%$ (275) had experienced a problem at least once in their lives. The percentage of respondents who believed acne to be an adolescent's problem was $22.1 \%$ (103) before seminars, while this figure decreased to $9.7 \%$ (49) afterwards. Participants' answers to questions regarding the causes of acne are shown in Table 2 . In total, $31.1 \%$ of participants responded positively to the statement "acne stems from the liver, and it should definitely be investigated," while this rate fell to $16.7 \%$ after the seminar, and the rate of undecided decreased from $48.8 \%$ to $6.2 \%$. Before the informative seminar, $11.6 \%$ of participants thought that acne was contagious; however; this ratio decreased to $2.8 \%$ after the seminar. Before the seminar, $78.5 \%$ of the participants believed that acne was related to diet, and this rate increased to $93.1 \%$ after the seminar. When the participants were questioned on their quality of sleep before the seminar, $44.2 \%$ stated that it had no effect, while $90.3 \%$ stated that it would have an effect after the seminar. Before

Table 1. Questionnaire for acne seminar participants

1. Have you ever had acne complaints?

2. Is acne only seen in adolescence?

3. What do you think is the reason for acne? More than one option can be chosen.

4. Acne stems from the liver and it certainly requires a blood test. Do you agree?

5. Is acne contagious?

6. Is acne related to the diet (fatty, junk food)?

7. Are smokers more prone to acne?

8. Do you think a stressful life causes more acne?

9. Does the quality of sleep affect acne?

10. Does doing sports play a role on improving acne?

11. Should acne certainly be treated?

12. I believe that skin cleansing (washing the face daily with the right soap) plays an important role in acne treatment.

13. Where do you obtain acne information and treatment from?

14. How long do you think your acne treatment suggested by your doctor will last?

15. Do you use the same prescription as your friend when they benefit from it?

16. When I get treated for my acne, I will never have it again. Do you agree?

17. Do you think ads such as "stop acne in 3 days" are believable?

18. Acne medication causes infertility. Do you agree with this statement?

19. Acne medication damages my liver. Do you agree with this statement?

20. Acne medication ruins my psychology. Do you agree with this statement? 
the seminar, $58.4 \%$ of participants believed that acne must certainly be treated, and $41.4 \%$ thought it would be untreated; however, the percentage who thought acne must be treated increased to $95.9 \%$ after the seminar. Table 3 shows the resources participants reported consulting about information and treatment alternatives for acne. In all, $51.1 \%$ of participants replied " 1 or 2 weeks" to the question "How long do you think the treatment your doctor recommended will last?" whereas the frequency of the response " 2 or 3 months to see the effects once treatment is received" increased from $24.7 \%$ to $83 \%$ after the seminar. The percentage of participants who thought they could use the same prescription that their friend benefited from was $28.5 \%$ before the seminar and $4.7 \%$ afterwards. Before the seminar, $10.3 \%$ thought acne medications led to infertility, decreasing to $4.9 \%$ after the seminar; those who thought this statement was incorrect increased from $30.7 \%$ to $88.8 \%$ after the seminar. The percentage of undecided respondents decreased from $58.6 \%$ to $5.8 \%$. When participants' responses were compared regarding the resources they could consult to obtain information about acne, 35.3\% of undecided respondents consulted doctors and $21.6 \%$ consulted the internet/media. After the seminar, the percentage of participants who thought acne medication could harm the liver decreased to $9 \%$ from $26.2 \%$. The percentage who believed this statement to be incorrect increased from $19.7 \%$ to $83.7 \%$, and the rate of undecided respondents decreased to $7.2 \%$ from 54\%. When the participants' educational background was grouped as "secondary-high school-other," there was no statistically significant difference $(p=0.318)$ in terms of their opinions about acne medication harming the liver; the responses after the seminar showed a statistically significant difference $(p=0.005)$. When they were asked

Table 2. Participants' responses to the causes of acne

\begin{tabular}{|l|l|l|l|l|}
\hline \multirow{2}{*}{} & \multicolumn{2}{|l|}{ Before seminar } & \multicolumn{2}{l|}{ After seminar } \\
\cline { 2 - 5 } & $\mathbf{n}$ & Percentage & $\mathbf{n}$ & Percentage \\
\hline Stress & 223 & $\mathbf{2 5 . 5 0} \%$ & 109 & $15.50 \%$ \\
\hline Diet & 245 & $\mathbf{2 8 . 0 0} \%$ & 114 & $16.20 \%$ \\
\hline Hormones & 145 & $16.60 \%$ & 70 & $9.90 \%$ \\
\hline Genetics & 60 & $6.90 \%$ & 47 & $6.70 \%$ \\
\hline All & 187 & $21.40 \%$ & 359 & $\mathbf{5 0 . 9 0} \%$ \\
\hline Other & 14 & $1.60 \%$ & 6 & $0.90 \%$ \\
\hline Total & 874 & $100.00 \%$ & 705 & $100.00 \%$ \\
\hline
\end{tabular}

Table 3. Participants' resources about the acne information and treatment

\begin{tabular}{|l|l|l|l|l|}
\hline \multirow{2}{*}{} & \multicolumn{2}{|l|}{ Before seminar } & \multicolumn{2}{l|}{ After Seminar } \\
\cline { 2 - 5 } & $\mathbf{n}$ & Percentage & $\mathbf{n}$ & Percentage \\
\hline Friend & 81 & $13.0 \%$ & 29 & $5.30 \%$ \\
\hline Doctor & 293 & $\mathbf{4 7 . 6 0} \%$ & 421 & $\mathbf{7 7 . 0 0} \%$ \\
\hline Pharmacist & 51 & $8.30 \%$ & 38 & $6.90 \%$ \\
\hline Neighbor & 9 & $1.50 \%$ & 4 & $0.70 \%$ \\
\hline $\begin{array}{l}\text { Internet/magazine/ } \\
\text { newspaper }\end{array}$ & 147 & $\mathbf{2 3 . 9 0} \%$ & 49 & $9.00 \%$ \\
\hline Herbalist & 35 & $5.70 \%$ & 6 & $1.10 \%$ \\
\hline Total & 616 & $100.00 \%$ & 547 & $100.00 \%$ \\
\hline
\end{tabular}

about their thoughts on whether acne medication had an impact on their psychology, 23.8\% responded that it "has an effect," $37.8 \%$ responded "does not affect" and 38.4\% responded as "undecided." The percentage of participants who thought it had no effect increased to $68.2 \%$ after the seminar. In all, $93.8 \%$ (437) of the participants stated that they benefited from the seminar, and many of the questions they had in their minds were answered.

\section{Discussion}

Although there are many studies on the etiopathogenesis of acne in the literature, research aiming to gain insight on patients' level of knowledge of acne from their perspective is scarce ${ }^{1-9}$. Rasmussen and Smith $^{2}$ reported in their study that individuals of a similar age and gender composition blamed food (chocolate) 32\% and $72 \%$ stress for the etiology of acne. Kaushik et al. ${ }^{1}$ stated that $85 \%$ of acne patients attribute the etiology of acne to food and $46 \%$ to mood changes. In the present study, before the seminar, while participants believed that diet and stress were the most significant factors affecting acne, they stated that several factors, such as stress, hormones, and genetics might cause acne. Kaushik et al. ${ }^{1}$ reported that individuals consulted friends (45.5\%), family (35\%), and the internet (22.5\%) for gathering information regarding acne. On the other hand, Karciauskiene et al. ${ }^{5}$ detected family, magazines, and friends, in that order. In our study, $47.6 \%$ of participants consulted doctors, $23.9 \%$ the internet and $13.1 \%$ friends. This result can be explained by the higher number of educated individuals in this study, compared with previous works.

Acne is known to be a sign of adolescence and thought be over after adolescence. Even though mild case of acne does not cause a serious problem, patients do not consult a doctor as they think that treatment is not necessary, even for scar-leaving acne; unfortunately, this causes life-long acne scars. In a study by Machiwala et al. ${ }^{6}, 57 \%$ of patients stated that acne should certainly be treated, $22 \%$ had no idea, and $21 \%$ defined it as a situation that regresses without treatment. In our study, $58.4 \%$ of patients stated that it should be treated and $41.4 \%$ thought it could regress on its own. Al-Natour ${ }^{7}$ investigated 329 male patients in his study, and $58.9 \%$ stated that it required no treatment. Among these differences, Al-Natour's ${ }^{7}$ study consisted of a male majority, and Machiwala et al.' ${ }^{6}$ study consisted of a female majority; the fact that female cosmetic awareness and acne treatment expectations are higher may have played a role here. As for the question, "how long do you expect acne treatment to take?," while $52.1 \%$ participants responded " 1 or 2 weeks," similar to our study, $52 \%$ of patients in Al-Natour's ${ }^{7}$ study reported expecting a complete cure in a very short time or after a doctor's visit. However, in Reich et al.' $\mathrm{s}^{8}$ study, the rate was $20 \%$ and similar that in to Al-Natour's $\mathrm{s}^{7}$ study, especially as those with no acne history considered it to be a temporary situation requiring no treatment. In our study, as a result of the fact that most of our participants were female, more than half had a history of acne, and an impatient group of adolescents hoping to meet instant expectations makes us think that they expect solutions in a short time.

In our study, $77.7 \%$ of respondents considered acne not to be contagious. Likewise, Su et al. ${ }^{9}$ found this rate to be $82.2 \%$, and acne was reported to be a problem related to lack of hygiene and inappropriate skin cleaning rather than being an infectious situation. There are different points of view regarding acne and the quality 
of sleep. In our study, $44.2 \%$ participants stated that acne had no correlation with sleep quality, whereas according to Wisuthsarewong et al. ${ }^{10}$, lack of sleep played an important role as a factor in acne development, with $65.5 \%$ of respondents answering in the affirmative to this question; similarly, in a study by Suthipinittharm et al. ${ }^{11}$, more than half of the participants stated a relationship between acne and sleep quality, but these comments mostly referred to people under emotional stress. Bilgiç et al. ${ }^{12}$, however, reported that a good sleep pattern increased the sebum in the T-zone in female patients with acne vulgaris, and this is accepted as a factor that protects the skin by forming a barrier to oxidative damage, such as from UV rays, with an antimicrobial impact.

Patients have different views on systemic isotretinoin use and serious prejudices about the side effects of this treatment. This sometimes causes patients or their families to reject the treatment. Especially, infertility is thought to result from isotretinoin use because of its teratogenic effects, and liver deficiency is believed to be occurring as a result of the impact on liver tests. For the question regarding "the effect of systemic isotretinoin treatment on infertility," $10.3 \%$ of participants thought it would cause infertility, 58.6\% were undecided, and after the seminar, the rate of undecided responses decreased to $5.8 \%$. There are no studies on patients' views about this. Before the seminar, 54\% of participants had no idea on "the fact that systemic isotretinoin might harm the liver," whereas $26.2 \%$ replied positively, and after the seminar, $83.7 \%$ believed that isotretinoin had no harmful effect on liver. Before the seminar, participants were reported to consult doctors first, and they consulted the internet/media as a source of information about the effect of systemic treatment on infertility and liver damage secondarily when their source of information was compared. Yet, individuals tended to remember or believe the information they receive through media to a greater extent. This shows the important role of the media in perception management and raising awareness. There are also studies showing that systemic isotretinoin may cause several psychosocial side effects, such as suicide attempts or depression, as a result of corrupting serotonergic signaling and slowing neurogenesis ${ }^{13,14}$. The risk is stated to be especially high in individuals prone to emotional mood disorders ${ }^{14}$. In our study, $37.8 \%$ responded, as it had no effect on psychology, 38.4\% were undecided, and after the seminar, the percentage of those who believed that it had no effect on psychology increased to $68.2 \%$.

Especially in our society, many skin diseases are misbelieved to result from the liver, primarily acne. Our study reached similar conclusions. However, correcting the misconceptions of the community after the seminars showed that doctors have an important role in raising awareness among people. When participants' educational background was grouped as "secondary-high school-other," high school graduates' responses showed a significant difference compared with others, and the educated group benefited more from the seminars.

\section{Study Limitations}

The participants consisted of a heterogeneous group in terms of socioeconomic and cultural backgrounds and educational levels. It is also a restrictive point that the same presentation contents were used by different physicians, but the seminars were given only once. How much information is received, processed, and retained by participants who fill out the questionnaire forms after the seminar may vary according to the differences between the instructors and the learning skills of the participants themselves. These parameters have not been evaluated.

\section{Conclusion}

There has been no previous comparative study regarding this, yet it is considered that the more educated the participants, the more they benefit from the seminars. On the other hand, simplifying the language of education seminars according to the target audience and removing terminology will increase understandability. Including such educational programs in school curriculum and organized presentations through media or institutions will prevent individuals from consulting incorrect resources, provide more realistic expectations clear of prejudices, and improve their treatment adaptations.

\section{Ethics}

Ethics Committee Approval: İstanbul Medeniyet University, Göztepe Training and Research Hospital Local Ethics Committee approval was obtained (approval number: 2019/0113).

Informed Consent: It was obtained.

Peer-review: Externally peer-reviewed.

\section{Authorship Contributions}

Concept: H.K.Ö., A.S.K., Design: H.K.Ö., K.G., A.S.K., Data Collection or Processing: H.K.Ö., K.G., H.Ö., A.Ş.A., F.T.D., T.Ö.A., Analysis or Interpretation: H.K.Ö., K.G., H.Ö., A.S.K., Literature Search: H.K.Ö., Writing: H.K.Ö., K.G., A.S.K.

Conflict of Interest: No conflict of interest was declared by the authors.

Financial Disclosure: The authors declared that this study received no financial support.

\section{References}

1. Kaushik M, Gupta S, Mahendra A: Living with Acne: Belief and Perception in a Sample of Indian Youths. Indian J Dermatol 2017;62:491-7.

2. Rasmussen JE, Smith SB: Patient concepts and misconceptions about acne. Arch Dermatol 1983;119:570-2.

3. Jović A, Marinović B, Kostović K, Čeović R, Basta-Juzbašić A, Bukvić Mokos Z: The impact of pyschological stress on acne. Acta Dermatovenerol Croat 2017;25:1133-41

4. Claudel JP, Auffret N, Leccia MT, Poli F, Dréno B: Acne and nutrition: Hypotheses, myths and facts. J Eur Acad Dermatol Venereol 2018;32:16317.

5. Karciauskiene J, Valiukeviciene S, Stang A, Gollnick H: Beliefs, perceptions, and treatment modalities of acne among schoolchildren in Lithuania: A cross-sectional study. Int J Dermatol 2015;54:e70-8.

6. Machiwala AN, Kamath G, Vaidya TP: Knowledge, belief, and perception among youths with acne vulgaris. Indian J Dermatol 2019;64:389-91.

7. Al-Natour SH: Acne vulgaris: Perceptions and beliefs of Saudi adolescent males. J Family Community Med 2017;24:34-43.

8. Reich A, Jasiuk B, Samotij D, Tracinska A, Trybucka K, Szepietowski JC: Acne vulgaris: what teenagers think about it. Dermatol Nurs 2007;19:49-54.

9. Su P, Chen Wee Aw D, Lee SH, Han Sim Toh MP: Beliefs, perceptions and psychosocial impact of acne amongst Singaporean students in tertiary institutions. J Dtsch Dermatol Ges 2015;13:227-33.

10. Wisuthsarewong W, Nitiyarom R, Kanchanapenkul D, Arunkajohnask S, Limphoka P, Boonchai W: Acne beliefs, treatment-seeking behaviors, information media usage, and impact on daily living activities of Thai acne patients. J Cosmet Dermatol 2020;19:1191-5. 
11. Suthipinittharm P, Noppakun N, Kulthanan K, et al: Opinions and perceptions on acne: A community-based questionnaire study in Thai students. J Med Assoc Thai 2013;96:952-9.

12. Bilgiç Ö, Bilgiç A, Altinyazar HC. Relationship between sleep quality and facial sebum levels in women with acne vulgaris. Indian I Dermatol Venereol Leprol 2016;82:313-4.

13. Metekoglu S, Oral E, Ucar C, Akalin M: Does isotretinoin cause depression and anxiety in acne patients? Dermatol Ther 2019;32:e12795.
14. Suuberg A. Psychiatric and developmental effects of isotretinoin (retinoid) treatment for acne vulgaris. Curr Ther Res Clin Exp 2019;90:27-31. 